\title{
Ketterä oppiminen auttaa venymään
}

Kupias, Päivi \& Peltola, Raija (2019). Oppiminen työssä. Gaudeamus. 263 sivua.

KUN ARVOSTETTU tietokirjakustantaja Gaudeamus julkaisee kirjan työssä oppimisesta, sitä on tervehdittävä ilolla. Odotukset ovat korkealla.

Työssä oppimiseen on kiinnitetty Suomessakin 1980-luvun lopulta lähtien enenevästi huomiota. Jo työelämään siirtyneiden pitäisi jatkuvasti uudistaa osaamistaan työn muuttuessa, jotta yritykset saavat pidettyä yllä kilpailukykyään markkinoilla. Nuorille tarjottavaa ammatillista opetusta taas siirretään yhä enemmän työelämään. Näin säästetään resursseja, kun nuorten ei tarvitse istua koulunpenkillä vuosikausia pänttäämässä "turhaa teoriaa" - eikä oppilaitoksissa edes opita "oikeita töitä".

Oppiminen työssä -kirjan tekijät ovat työnohjaajia, jotka harjoittavat ammattiaan omistamassaan Tevere-osakeyhtiössä. Kirja koostuu kuudesta luvusta, joissa käsitellään työtä oppimisympäristönä ja avataan aihetta oppijan näkökulmasta. Oman lukunsa saavat oppimisen tukeminen, tiimioppiminen ja organisaation oppiminen sekä oppimisen tulevaisuus.

Kirja lähtee jutustellen liikkeelle. Siellä tälllä viljellään vanhoja sanontoja: "Työ tekijäänsä opettaa", "Rapatessa roiskuu" tai "Ei kannettu vesi kaivossa pysy". Pian lukijalle käy selväksi, että teos ei ole tutkimus tai muiden tutkimustuloksia syntetisoiva tie- tokirja. Sitä varten ei ole tehty empiiristä tutkimusta, eikä tekijöillä ole käytössään empiiristä aineistoa esityksensä perustaksi. Jonkin verran he viittaavat siihen, millaisiin tilanteisiin ja tapauksiin he ovat työnohjaajina törmänneet.

Sen sijaan kirjassa on kuvauksia työpaikoilta ja yksittäisten työntekijöiden ja työntekijäryhmien ajattelusta ja toiminnasta. Ne esitetään tekstissä kursivoituina kappaleina ikään kuin todisteina sanotulle, mutta tarinat ovat kirjoittajien itsensä keksimiä. Näin he ovat säästäneet itseltään aineistojen keräämisen ja analysoimisen vaivan.

\section{FIKTIOITA FAKTOJEN \\ PUUTTEESEEN}

Työssä oppimista koskevaan tutkimukseen perehtyminen on jäänyt tekijöiltä vähäiseksi: lähdekirjallisuus on suppeaa ja satunnaisesti valikoitunutta. Kansainvälisesti tunnetuista tutkimuksista mukana ovat vain Dreyfus \& Dreyfus (1986), Kolb (1984), Mezirow (1991) ja Senge (1990), jotka ovat 30 vuoden takaa.

Tekijät luonnostelevat kolme yritystyyppiä, joilla he kuvailevat erilaisia yrityskulttuureja ja oppimisympäristöjä: monikansallinen liikunta-alan yritys YX Fitness, koulutusta tarjoava ja kehittävä yritys Polunraivaajat ja siivousalan

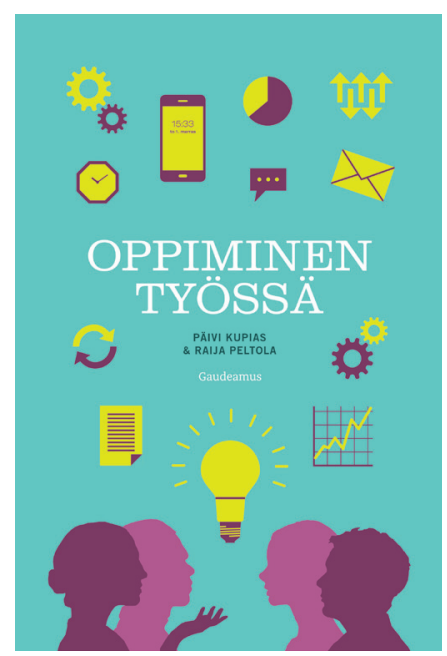

osuuskunta Koti-inno. Tyyppiyritysten yhteyttä reaalimaailman ei käsitellä.

Kirjoittajat ovat siis itse keksineet ihmisistä ja työpaikoista tarinoita, joita käyttävät kirjassaan. Lukijalle ei esitetä empiirisiä todisteita tai edes arvioita, miten tavallisia tämän tyyppiset yritykset ovat Suomessa tai maailmalla, tai kuinka suuri osuus työvoimasta työskentelee tällaisissa yrityksissä.

\section{LUOKITTELUA JA NIMEÄMISTÄ}

Kirjassa on runsaasti erilaisia luokitteluja, joita ei yleensä perusteta sen enempää teoreettiseen kuin empiiriseen tutkimukseen: On erilaisia työpaikkoja, joissa on erilaisia oppimisympäristöjä. On tämmöisiä, tuommoisia ja semmoisia.

Samalla periaatteella luokittuu oppiminen: on toistavaa, ymmärtävää ja luovaa oppimista. Työelämän valmentaja voi olla fasilitaattori, työnohjaaja, coach, mentori, tuutori, perehdyttäjä tai 
asiantuntijakouluttaja. Organisaation kehittäminen voi olla sopeuttavaa, dialogista tai käänteistä. Työelämän tiimit voivat olla joukkioita, joukkoja, joukkueita tai huippujoukkueita. Työpaikalla toimiva ryhmä voi olla pelkäävä, varovainen, perusturvallinen tai luottavainen.

Luokittelut eivät palvele työssä oppimisen teoreettista jäsennystä vaan jääuät nimeämiseksi. Luokittelun ja luokkien nimeämisen yhteys empiiriseen todellisuuteen jää hämärän peittoon. Emme saa tietää, miten kattavia luokittelut ovat tai mikä on eri luokkien suhde niin sanottuun todellisuuteen.

Empiirisen todellisuuden syrjäyttäminen johtaa siihen, että kirjan tärkein käsite ja ilmiö, 'oppiminen', jää abstraktioksi, joka ei tunnista työelämän oppimisen ja koulutuksen yhteyksiä esimerkiksi palkkatyön luonteeseen, yhteiskuntaluokkaan, työelämän valtasuhteisiin tai sukupuoliseen segregaatioon.

\section{KETTERÄSTI TULEVAISUUTEEN}

Organisaation oppimista ja oppivaa organisaatiota luonnehtivassa luvussa tekijät ihastuvat tutkija Leenamaija Otalalta lainaamaansa 'ketterään oppimiseen'. Se on vastaus nopeasti muuttuvan ja monimutkaistuvan organisaation tarpeisiin. Siihen kuuluu oppimispyrähdyksiä ja oppimishyppyjä: "ketterässä oppimisessa oppimiselle annetaan mahdollisuus", ja "ketterä oppija oppii monipuolisesti”. Ketteryyttä kuvataan kuminauhana, se perustuu nimenomaan venymiseen. Jos kuminauhaa kuitenkin venyttää liikaa, se voi katketa. (s. 191) Yhtä kaikki, ketterä oppiminen päivittää oppivan organisaation ajatuksen nykyaikaan.

"Työssä oppimisen suunta" -päätösluvussa tekijät tunnustavat, kuinka vaikea aihe työssä oppiminen on ja kuinka haasteellista siitä on hahmottaa kokonaiskuvaa. Yksi syy vaikeuksiin on se, että tekijät eivät tunnu perehtyneen aihepiiristä tehtyyn tutkimukseen, vaikka sitä on runsaasti saatavilla. Kirjallisuus työelämän muutoksesta ja työssä oppimisen trendeistä jää sekin hyödyntämättä päätösluvussa.

\section{TIETOKIRJA VAI ELÄMÄNTAITO- OPAS?}

Gaudeamus tunnetaan niin yliopistollisiksi oppikirjoiksi kelpaavista tutkimuksista kuin kulttuuriteoiksi arvioiduista klassikkokäännöksistä. Vastapainon ohella se on Tieteellisten seurain valtuuskunnan (TSV) JUFO-luokituksessa tasolla 2, mikä tarkoittaa, että lukija voi odottaa kustantajalta tasokasta tieteellistä kirjallisuutta. Oppiminen työssä -kirjaa lukiessa joutuu koko ajan puntaroimaan, lukeutuuko se ylipäätään tietokirjoihin.

Tyyliltään kirjan teksti lähenee elämäntaito-opasta. Se kannustaa itse kutakin reflektoimaan tekemisiään ja arvioimaan itseään oppijana tai muiden oppimisen tukijana. Kymmenillä ellei sadoilla kysymyksillä koetetaan aktivoida lukijaa ajattelemaan: "Ovatko kaikki työpaikat hyviä paikkoja oppia?" tai "Pitääkö oppijoiden saada uut- ta tietoa?" Usein kysymyksillä puhutellaan työnohjaajia ja esimiehiä.

Lisäksi lukijalle annetaan toimintaohjeita: "Jos sinulla on oikein vaikea tilanne ratkaistavana, hellitä hetkeksi ja kuuntele, mitä kumpuaa sisältäpäin. Voit vaikka nukkua yön yli. Ratkaisu voi putkahtaa yllättäen.” (s. 68)

Kuin todisteeksi ohjeen toimivuudesta kirjoittajat tarjoavat keksimänsä tarinan Polunraivaajien kokeneesta kouluttajasta Pertistä, joka tarvitsi aivan uudenlaista ohjausta asiakkaan tarpeen tyydyttämiseksi: "Pertillä ei ollut aavistustakaan, kuinka hän ongelman ratkaisisi. Hän päätti kuitenkin olla luottavainen ja asiaa ensin asiakkaan sekä muutaman kollegan kanssa pohdittuaan päätti työstää asiaa alitajunnassaan. Pertti keskittyi muihin asioihin ja viikon päästä palasi asiaan. Alitajunta oli tehnyt tehtävänsä, ja hänellä oli selkeä suunnitelma, kuinka toimia." (s. 69)

\section{NIMEN JA SISÄLLÖN EPÄSUHTA}

Esipuheessa kirjoittajat sanovat, että "kirja käsittelee oppimista, työtä ja erityisesti työssä oppimista”. No, käsittelee ja käsittelee. Jos lukija etsii teosta, jossa oppimista, työtä ja työssä oppimista jäsennetään viimeaikaisten teoreettisten kehittelyjen ja uusimpien empiiristen tutkimustulosten avulla, kirjasta ei ole apua. Esimerkiksi korkeakouluopiskelijoiden lukemistoksi se ei sovi.

Sinänsä sujuvasanaisesti kirjoitetun kirjan 260 sivuun sisältyy niin paljon jutustelua ja sisällyksettömiä lauseita, että sen lukeminen 
voi olla konsulteille ja työnohjaajillekin turhauttavaa. Kunkin luvun päättävät koosteet palvelevat kiireistä lukijaa mutta paljastavat samalla, miten vähän uutta tietoa tai uusia tulkintoja tekijät ovat saaneet niihin poimituksi.
Lukijalle syntyy vaikutelma, että kirjoittajat ovat vain litteroineet pitämiään koulutustilaisuuksia kansien väliin.

Kirja on nimetty virheellisesti. "Oppiminen työssä" johtaa harhaan.

\section{HEIKKI SILVENNOINEN}

VTT, professori

kasvatustieteiden laitos, Turun yliopisto

\section{Tutkijat katsovat koulutuksen tulevaisuuteen}

Pohjoismaiden Nordic Educational Research Association (NERA) tuo kasvatustieteiden tutkijat Turkuun ensi vuoden maaliskuussa. Vuosittaisen kongressin teema on ajankohtainen ja tärkeä: koulutuksen tulevaisuus Pohjoismaissa.

NERA-kongressin järjestelyistä vastaavat kasvatustieteiden tiedekunnan yksiköt: kasvatustieteiden laitos ja sen Elinikäisen oppimisen ja koulutuksen tutkimuskeskus (CELE) sekä opettajankoulutuslaitos. Kansainvälinen kongressi on järjestäjien mukaan oivallinen paikka esitellä suomalaista tutkimusta kansainväliselle yleisölle ja verkostoitua tutkijoiden kesken.

NERA on organisoitunut 25 teemaryhmäksi. Kongressin esiintyjät ovat kansainvälisesti tunnettuja tutkijoita, kuten koulutuksen globalisaation tutkija, professori Fazal Rizvi Melbournen

\author{
yliopistosta ja opetuksen ja -oppimisen \\ analyytikko, professori Kirsti Klette \\ Oslon yliopistosta sekä professori Risto \\ Rinne Turun yliopistosta. \\ Paneelikeskustelussa kongressin \\ teemaa lähestytään korkeakoulutuksen \\ näkökulmasta. "Actors and ideas \\ shaping the future of higher \\ education" -paneeli tuo saman pöydän \\ ääreen professorit Ivar Bleiklien \\ Bergenin yliopistosta, Jussi Välimaan \\ Jyväskylän yliopistosta ja Susan \\ Wrightin Aarhusin yliopistosta.
"Korkeakoulutukselle asetetaan monia ristiriitaisia uudistumispaineita, joiden laajempia seurauksia on vaikea ennustaa. Muutokset tulevat kuitenkin vaikuttamaan meidän kaikkien töihin", kommentoi apulaisprofessori Ulpukka Isopahkala-Bouret kongressin järjestelytoimikunnasta.

\section{NERA-kongressi}

- järjestään 4.-6. maaliskuuta 2020

- on järjestyksessä 24.

- käydään virallisesti englanniksi, mutta ruotsi on rinnakkaiskielenä

- odottaa abstrakteja viimeistään 15. marraskuuta 2019

- ottaa vastaan ilmoittautumisia 15. marraskuuta 2019 - 19 helmikuuta 2020.

Lisätiedot: nera2020.fi 